\title{
Vocabulario de las Filosofías Occidentales. Diccionario de los intraducibles, Barbara Cassin (dir.)
}

\author{
María Natalia Prunes
}

Universidad de Buenos Aires

Argentina

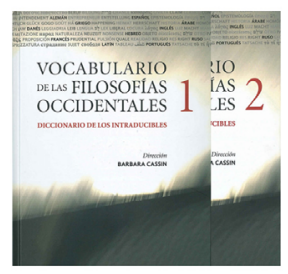

Cassin, Barbara (dir.). Vocabulario de las filosofias occidentales (2 tomos). Ciudad de México: Siglo XXI editores, 2018.
El Vocabulario de las Filosofías Occidentales. Diccionario de los intraducibles, publicado recientemente por la editorial Siglo xxi de México, es una traducción al español y adaptación al contexto hispanoamericano del ya célebre Vocabulaire des Philosophies Européens. Dictionnaire des intraduisibles (VEP), dirigido por Barbara Cassin y publicado por la editorial Du Seuil/ Le Robert en 2004. La autora conceptual, directora de investigación del Centro Nacional para la Investigación Científica de Francia (CNRS) y elegida en mayo de 2018 como miembro de número de la Académie Française (la novena mujer en toda la historia de la institución), ha confesado en diversas oportunidades que tomó como modelo el objetivo pluralista y comparatista del Vocabulario de las instituciones indoeuropeas de Émile Benveniste, en un gesto filosófico y político a la 
vez. La apuesta filosófica radica en el hecho de comprender que filosofamos en lenguas, entendiendo la lengua no como un mero instrumento de comunicación, sino como "una red diferente echada al mundo que trae otros peces y diseña otro mundo". ${ }^{1}$ El gesto político más explícito, por su parte, se opone directamente a la corriente que promueve el llamado global English como lengua hegemónica y privilegiada en ámbitos como el científico y académico que atenta contra el fundamento humboldtiano de que el lenguaje se manifiesta en la realidad únicamente a partir de su multiplicidad.

El Vocabulaire Européen des Philosophies. Dictionnaire des intraduisibles, así, se basa en la intrínseca dificultad de la traducción en el ámbito de la filosofía, de manera que, tal como afirma Cassin en la Presentación, no se trata de un compendio de conceptos, sino más bien, de un conjunto de lexemas considerados intraducibles, en tanto son síntomas de la diferencia entre lenguas. Vale decir que la intraducibilidad entre dos palabras no radica en la imposibilidad de encontrar un lexema apropiado para expresar en una lengua lo que ha sido manifestado en otra, sino en la capacidad infinita de traducciones posibles, en una búsqueda incesante de superar, justamen-

1 Barbara Cassin, "Les intraduisibles", Revista Sciences/Lettres, núm. 1, año 2013. https://journals. openedition.org/rsl/252\#quotation Fecha de consulta: 28 de noviembre de 2018 . te, aquella diferencia entre las distintas lenguas. Esto es en particular evidente en el caso de las traducciones de los clásicos, los cuales, justo, mantienen su vigencia porque son repensados en las distintas épocas de recepción de los textos. Como bien indica María Isabel Santa Cruz en su artículo "Traducir a los clásicos. Algunas reflexiones", 2 "toda traducción es obra de un presente y está sujeta a revisión", en la medida en que se trata de lograr en el receptor contemporáneo un efecto lo más cercano posible a la intencionalidad del autor original aquello escrito en otra lengua y en otro tiempo y/o contexto de enunciación.

Por lo tanto, la traducción del Vocabulaire Européen des Philosophies. Dictionnaire des intraduisibles al español no podía dejar de lado un proceso de adaptación al contexto de recepción de la obra: el universo hispanoamericano. Como se sabe, en América, a partir de los contactos entre europeos y pueblos originarios y entre la lengua importada de España y las lenguas amerindias "surgió una fusión de voces y una confusión semántica que produjo palabras y formas de pensamiento inéditas" ${ }^{3}$ expresadas en dis-

${ }^{2}$ María Isabel Santa Cruz, "Traducir a los clásicos. Algunas reflexiones" en Studium philosophiae. Textos en homenaje a Silvia Magnavacca, Claudia D’Amico y Antonio Tursi coords. (Buenos Aires, Rhesis, 2014), 372.

${ }^{3}$ Jaime Labastida, El universo del español. El español del universo (México, Academia Mexicana de la Lengua Espańola, 2014), 14. 
tintos géneros discursivos, no siendo la filosofía el privilegiado entre ellos debido a las situaciones político-económicas dominantes que afectaron el desarrollo del pensamiento crítico en determinados marcos académicos o instituciones de poder. No por ello, géneros como la novela (baste pensar en el llamado boom latinoamericano), el ensayo, la polémica pública o el periodismo han sido más permeables a desarrollar una identidad pensada en lengua española tan influida por Europa como influyente en ella. Así pues, ya desde el propio título vemos un gesto nada ingenuo de adaptación/ apropiación del original: el paso del Vocabulaire Européen des Philosophies al Vocabulario de las Filosofías Occidentales implica que ya no se trata de un vocabulario europeo, sino un vocabulario occidental, de forma tal que el foco se ha ampliado para poder englobar América y las formas de pensamiento en lengua espańola que se veían relegadas o incluso ignoradas en la versión francesa, en donde el peso de la filosofía clásica antigua y el idealismo alemán, además de algunas otras disciplinas cuyas problemáticas no escapaban del etnocentrismo europeo, eran los protagonistas. $\mathrm{Al}$ menos, así lo entendían los coordinadores de la adaptación al español, la especialista en historia de la lengua española y enseñanza de lenguas extranjeras María Natalia Prunes y el experto en culturas latinoamericanas e ibéricas
Guido Herzovich, ambos profesores e investigadores argentinos.

En consecuencia, al plantearse el problema de la adaptación/traducción, siempre supervisados bajo el coordinador general, Jaime Labastida, reconocido filósofo y poeta mexicano, director de la Academia Mexicana de la Lengua Española, Prunes y Herzovich tomaron la siguiente decisión: a diferencia de otros proyectos similares a éste, como el ucraniano, en donde se decidió hacer un recorte y una selección de los intraducibles originales que resultara de interés para el público al que iba dirigida la traducción, decidieron traducir del francés la obra íntegra, es decir, las cuatrocientas entradas léxicas, equivalentes a unos nueve millones de caracteres (proceso que se había iniciado hacía ya ocho años, en el marco de intentos anteriores que quedaron truncos), pero con una fuerte intervención devenida naturalmente en apropiación. Esto se refleja, a simple vista, en el hecho de que el Vocabulario de las Filosofias Occidentales. Diccionario de los intraducibles se extiende a dos volúmenes, en lugar de un solo tomo del francés, sobrepasando ampliamente la cantidad de caracteres del original, pese a que también ha habido supresiones, en la medida en que se han agregado siete nuevas entradas léxicas y numerosos nuevos recuadros hechos por reconocidos especialistas de habla espańola (en su mayoría, argentinos, pero muchos 
otros también de diversas nacionalidades y afiliaciones académicas), centradas en las problemáticas propiamente iberoamericanas, además de que se incluyeron algunos recuadros y entradas léxicas originales del Dictionary of untranslatables. A Philosophical Lexicon ${ }^{4}$ y del proyecto de traducción/ adaptación del Vocabulaire Européen des Philosophies. Dictionnaire des intraduisibles al portugués aún inédito dirigido en Brasil por Fernando Santoro, así como también se agregó una entrada de la versión hebrea y otra de la árabe, ambas en curso. Se observa, entonces, que el desplazamiento del foco centrado en Europa hacia el pensamiento occidental, en general, no sólo implica una fuerte toma de posición de empoderar a América, sino que es también un modo de "provincializar a Europa” — según la expresión de Chakrabarty-, dándoles el lugar que merecen a los intraducibles propios del mundo multicultural y globalizado existente en y fuera de Europa.

El fruto de esta ímproba tarea de traducción y adaptación, coordinada por María Natalia Prunes, ha sido posible gracias a la colaboración de treinta y cuatro traductores, treinta y siete lectores especialistas de diversas disciplinas del pensamiento en lengua española, doce transliteradores (una

\footnotetext{
${ }^{4}$ Emily Apter, Jacques Lezra y Michael Wood, coords. Dictionary of untranslatables. A Philosophical Lexicon (Princeton University Press, 2014).
}

especialista en árabe, siete de griego, una de hebreo, uno de ruso y dos de sánscrito) y veinticuatro autores (sin contar aquellos que escribieron entradas en otras versiones del Vocabulaire Européen des Philosophies. Dictionnaire des intraduisibles y, como hemos dicho más arriba, fueron traducidas al español), además de las generosas y desinteresadas ayudas recibidas por parte de múltiples colegas y del equipo técnico de Siglo XxI, liderado por María Oscos. Sin duda, el resultado de este esfuerzo hercúleo se traduce en una apropiación de una obra que es interminable por definición y cuyo sello aspira a marcar las próximas ediciones/ traducciones/apropiaciones e invenciones del Diccionario de los intraducibles, obra de referencia ineludible para estudiantes universitarios, profesores, investigadores y público general no sólo interesados en la Filosofía, sino en las problemáticas actuales occidentales atravesadas por la globalización y pensadas en lengua española. 